\title{
Investigating the Moderating Effects of Leader-Member Exchange in the Psychological Contract Breach-Employee Performance Relationship: A Test of Two Competing Perspectives
}

\author{
Simon Lloyd D. Restubog, Prashant Bordia, Robert L. Tang ${ }^{1}$ and \\ Scott A. Krebs ${ }^{2}$
}

Research School of Business and School of Management, College of Business and Economics, Australian National University, Canberra, Australia, ${ }^{1}$ School of Management and Information Technology, De La Salle College of Saint Benilde, Philippines, and ${ }^{2}$ School of Psychology, University of Queensland, Australia

Corresponding author email: simon.restubog@unsw.edu.au

\begin{abstract}
Leader-member exchange (LMX) has been characterized as a form of social support capable of buffering the effects of negative work experiences. However, employees with high-quality relationships with leaders in the organization may have stronger negative reactions when psychological contracts are breached. Thus, while a social support perspective would suggest that LMX minimizes the adverse impact of psychological contract breach on employee performance, a betrayal perspective proposes that high LMX would aggravate the negative effects. Using cross-sectional and longitudinal research designs, results across three samples provided support for the betrayal perspective. That is, breach had a stronger negative relationship with organizational citizenship behaviours and in-role performance under conditions of high LMX. Implications of these results and future research directions are discussed.
\end{abstract}

One distinct work relationship that plays an important role in influencing employee attitudes and behaviours is the relationship between leaders and employees (Martin et al., 2005; Rafferty and Griffin, 2004). Given the importance of this work relationship, a great deal of theorizing and empirical research has been conducted to understand its nature and consequences. Leader-member exchange (LMX) has emerged as a prominent research area within the

We are grateful to Enrique Joseph Alvarez, Bobson Cardinal, Angelica Engco, Angela Gueco, Michael Madera, Angelita Vasquez and Domingo Zacarias for assistance in data collection. management and organizational sciences (Graen and Uhl-Bien, 1995; Maslyn and Uhl-Bien, 2001).

Existing research on LMX suggests that the quality of supervisor-employee relationships can serve as a form of social support in minimizing negative employment experiences (Erdogan, Kraimer and Liden, 2004; O'Driscoll et al., 2003). That is, employees in high LMX relationships are provided with affective and resourcebased support which can mitigate the influence of negative work experiences (cf. Erdogan, Kraimer and Liden, 2004). For example, in the context of psychological contract breach (i.e. failure to fulfil organization's promised obligations), Turnley and Feldman (1998) found that employees with 
supportive working relationships with their supervisors and co-workers were less likely to leave their organization and neglect in-role responsibilities. These findings suggest that leaders may be able to help employees better deal with psychological contract breach.

Taken from a different perspective, because high LMX relationships involve mutual trust, respect and obligations (Dansereau, Graen and Haga, 1975), this may impose greater expectations on the leader. As such, high LMX relationships may result in negative outcomes. For example, in a study of two organizational samples, Harris and Kacmar (2006) found that employees with high levels of LMX relationships with their supervisors reported more stress reactions compared to those with moderate quality LMX relationships. They surmised that relationships characterized with high LMX may be accompanied by extra pressure and obligations. In the context of our research, we propose that employees with high-quality relationships with leaders in the organization may respond in a more negative fashion when psychological contracts are breached. High LMX employees may in fact feel betrayed by psychological contract breach, and as a result be more disheartened by breach and reduce in-role performance and organizational citizenship behaviour (OCB). While both the social support and betrayal frameworks suggest that LMX can be a moderator variable, the pattern of effects differ between the two perspectives. The social support perspective would suggest that LMX buffers the effects of psychological contract breach on employee performance. In contrast, a betrayal perspective predicts that high LMX would exacerbate the negative effects. The use of competing perspectives is valuable especially when prior knowledge may potentially suggest two or more plausible explanations (Armstrong, Brodie and Parsons, 2001). Indeed, Chamberlin (1890, p. 94) noted that studying a particular phenomenon using competing perspectives reflects comprehensiveness because the predictions 'can encompass the subject on all sides, the total outcome of means and of methods is full and rich'. We begin by explaining the consequences of psychological contract breach on employee performance, and then introduce LMX as a moderator between breach and performance.

\section{Psychological contracts and employee performance}

A psychological contract is generally understood as a mental model which constitutes the terms and exchange agreement between the employee and his or her employing organization (Rousseau, 1995). Psychological contract research has predominantly focused on the organization as the referent (Rousseau, 1995). However, psychological contract theory does acknowledge that the development of one's psychological contract may arise from recruitment interviews, performance appraisals, written personnel policies or organizational practices derived from interactions with organizational agents (e.g. supervisors, human resources staff, senior managers; Deery, Iverson and Walsh, 2006; Rousseau, 1995; Rousseau and Greller, 1994; Shore and Tetrick, 1994). Because a psychological contract arises from sense-making processes (Rousseau, 1995), it is likely to be misinterpreted and may result in psychological contract breach. For example, an employer promises its employees that training opportunities and promotion will be given for outstanding performance. The employee exerts hard work to improve his/her performance, but if the organization does not provide such training and promotion opportunities this will result in psychological contract breach. In this example, the employee cognitively evaluates his/her contributions and outcomes against the contributions and outcomes that his/her employer has promised. Psychological contract breach therefore emanates from the employee's perception that there is a discrepancy between what was promised and what was actually delivered. A considerable body of research has demonstrated that psychological contract breach has negative consequences for organizations (Bordia et al., 2008a; Restubog, Bordia and Tang, 2006; Robinson, 1996; Robinson and Morrison, 2000; Robinson and Rousseau, 1994).

In this study, we examine individual effectiveness as a behavioural consequence of psychological contract breach. Individual effectiveness captures a range of behaviours including in-role performance and OCB (Harrison, Newman and Roth, 2006). In-role performance represents those aspects of employees' behaviours that are essential to the successful implementation of organizational operations (Podsakoff et al., 2000). 
It is generally defined by the specific knowledge, skills and competencies required for employees in order to function effectively in their job. It is also characterized by employees' responsibilities that are inherent to the organization's effectiveness which are translated into actual products or services.

OCBs are work behaviours which are voluntary in nature and transcend core job requirements (Podsakoff et al., 2000). They typically consist of social behaviours which are intended to benefit the organization and its constituents. Such behaviours support and facilitate the effective delivery of in-role performance (Turnipseed and Rassuli, 2005). An important characteristic of OCBs is that they are discretionary in nature (Podsakoff et al., 2000). As such, willingness to engage in these behaviours depends on the decision of the employee. Since these are not prerequisites of the job, there are no formal sanctions for failing to engage in them (Podsakoff et al., 2000). We examine two dimensions of OCBs: altruism and civic virtue behaviour. Altruism refers to discretionary behaviours that benefit co-workers such as helping to manage their workload and assist new co-workers while civic virtue behaviour reflects employees' active participation and concern about the life of the organization. Social exchange theory predicts that, if employees perceived that their organization is less willing to engage in a positive social exchange, then it is likely that employees will be less inclined to contribute to a positive exchange relationship (Blau, 1964). Indeed, a recent metaanalysis representing over 100 studies found that breach resulted in lower in-role performance and OCBs (Zhao et al., 2007).

\section{The moderating role of LMX: social support perspective versus betrayal perspective}

In this section, we consider the role of LMX in predicting employee behaviours and how it may influence the relationship between breach and these behaviours. LMX theory was developed to explain the quality of interpersonal relationship between an employee and his or her supervisor (Graen and Uhl-Bien, 1995). LMX proposes that leaders develop a different quality of relationship with each of their members. Social exchange (Blau, 1964) and the norm of reciprocity
(Gouldner, 1960) provide the framework for explaining the favourable consequences of higher quality leader-member relationships. The quality of these relationships determines the amount of physical or mental effort, material resources, information and/or social support exchanged between the supervisor and subordinate (Graen and Uhl-Bien, 1995). A high quality LMX relationship involves more exchange of effort, resources and support between the two parties. These relationships are characterized by liking, loyalty, professional respect and contributory behaviours. In contrast, low quality LMX relationships are characterized by minimal exchange of effort, resources and support between the two parties. Prior research has established LMX to be associated with subordinate OCBs and in-role performance (Tierney, Bauer and Potter, 2002).

We present two competing perspectives which may explain how LMX can influence the relationship between breach and performance. In the first perspective, LMX can be considered a source of social support that mitigates the negative impact of breach on performance. According to the stress-buffering mechanism in the social support literature (Cohen and Wills, 1985), support moderates the relationship between stressors and strains. The impact of stressors on strain is proposed to be stronger under low levels of support. In contrast, a weaker stressor-strain relationship is predicted when social support is high (Viswesvaran, Sanchez and Fisher, 1999). A basic premise of LMX theory implies that an employee's primary source of affective and resource-based support is his or her leader; this support has been found to buffer the effects of negative work experiences. For instance, Erdogan, Kraimer and Liden (2004) found that supportive relationships with the leader moderated the relationship between work value congruence and employee career satisfaction. Work value congruence is a type of person-organization fit, and is defined as the match between the organization's values (or culture) and the individual's values (Erdogan, Kraimer and Liden, 2004). Employees with low work value congruence were still satisfied with their careers when they were in a high LMX relationship. Similarly, O'Driscoll and colleagues (2003) found that social support, in the form of high quality LMX, moderated the relationship between work-to-family interference and psychological 
strain. Employees who experience a breach of psychological contract by their organization may not respond negatively if they believe that they are supported by their supervisor (Zagenczyk et al., 2009). In high LMX relationships, supervisors may offer explanations which may change employee attributions for breach. Supervisors can also provide career-related and psychosocial support and may even serve as an advocate for employees to the organization. Thus, a social support framework would suggest that, when subordinates enjoy high LMX status, the impact of negative work experiences such as breach on subordinate performance will be mitigated. However, when subordinates have low LMX, contract breach will have a stronger negative effect on subordinate performance. Thus, following a social support perspective, we hypothesize that:

H1a: LMX moderates the relationship between psychological contract breach and OCBs. The negative relationship between breach and OCBs would be weaker under high LMX as opposed to low LMX.

H2a: LMX moderates the relationship between psychological contract breach and in-role performance. The negative relationship between breach and in-role performance would be weaker under high LMX as opposed to low LMX.

An alternative explanation for LMX's influence on the relationship between psychological contract breach and performance can be derived from the betrayal framework (Elangovan and Shapiro, 1998). Betrayal is a serious violation of the norms and expectations of a relationship (Elangovan and Shapiro, 1998). In organizational settings, betrayals often result in employees not working as effectively (Reina and Reina, 1999) and possibly engagement in revenge-seeking behaviours on whoever betrayed them (cf. Bordia, Restubog and Tang, 2008). Personal expectations generally comprise the rules governing the relationship. These rules serve as the building blocks for trust within that relationship and help maintain the close ties between two parties (Elangovan and Shapiro, 1998). Previous research on social psychology of relationships noted that clearly the most significant type of betrayals involve one's close and important relationships (e.g. friends, parents, work colleagues and supervisors; Couch, Jones and Moore,
1999; Sias et al., 2004). Employees generally have an expectation that their supervisor will provide them adequate support. As high LMX relationships are characterized by a series of social exchanges resulting in mutual respect, trust and obligation (Graen and Uhl-Bien, 1995), failure on the part of the supervisor to prevent instances of breach may be considered as an act of betrayal. This violates employees' expectations regarding the trust, obligation and support that are supposedly inherent in high quality relationships. As a result, employees are likely to feel angry, resentful, bitter, mistreated and even enraged (Bordia, Restubog and Tang, 2008a; Morrison and Robinson, 1997).

Another theoretical explanation for the potential reverse-buffering effect of LMX can be drawn from cognitive dissonance theory which argues that dissonant or incongruent cognitions are likely to result in tension and strain (Beehr et al., 2003; Festinger, 1957). When the source of the stressor and support is the organization, employees are likely to experience conflicting cognitions. Major et al.'s (1997) notion of 'behavioural expectations' and 'mixed messages' further strengthens this explanation: psychological contract breach in the context of a supportive relationship may be more salient, and therefore have a stronger impact on employee performance because it is unexpected. Thus, using a betrayal framework, we predict that:

H1b: LMX moderates the relationship between psychological contract breach and OCBs. The negative relationship between breach and OCBs would be stronger under high LMX as opposed to low LMX.

$H 2 b$ : LMX moderates the relationship between psychological contract breach and in-role performance. The negative relationship between breach and in-role performance would be stronger under high LMX as opposed to low LMX.

We test the hypothesized relationships in three samples conducted with working adults as participants. In order to minimize common method variance, supervisor reports of performance were obtained in samples 1 and 2. Sample 3 involves a three-wave longitudinal design to test the competing perspectives. Altogether, the use of a multiple sample design and multi-source data is beneficial because it enables a strong test of the model and can better ascertain the internal validity of the results. 


\section{Method}

\section{Participants and procedure}

Samples 1 and 2. The human resources manager of the organization served as a liaison between the research team and the employees. Each participant received a survey pack comprising an information sheet (stating the aims of the study, confidentiality and voluntariness of participation), a self-reported questionnaire, and a supervisor-rated behavioural rating form. Both employees and supervisors completed questionnaires containing identity codes to permit matching. In order to increase response rates, participants were allowed to complete the questionnaires during their work time. Questionnaires (both self and supervisor rating forms) were returned directly to the research team.

In sample 1, surveys were distributed to 350 employees and their direct supervisors of a large manufacturing organization in the Philippines. A total of 250 employees completed the surveys, representing a response rate of $71.43 \%$. Out of the 250 surveys completed, 180 had matched supervisory ratings. Most of the participants were women $(67 \%), 64 \%$ were in the age group $21-30$ years, and $85 \%$ had been working with their organization for one to five years. Eighty-three supervisors completed the behavioural ratings, as each supervisor rated between one and three subordinates $($ median $=2.0$ ). One-way ANOVA testing (Bliese, 2000) for variations in supervisor ratings of OCB dimensions (e.g. altruism, $\mathrm{F}=0.38$, ns; civic virtue behaviour, $\mathrm{F}=0.83$, ns) across supervisor groups revealed no significant differences.

In sample 2, surveys were distributed to 200 sales personnel and their direct supervisors in a large pharmaceutical organization in the Philippines. A total of 158 participants completed the surveys, yielding a response rate of $79 \%$. Of this number, 142 participants had matched supervisory ratings. There was an even number of males and females. Almost half of the participants $(40.5 \%)$ were between 21 and 30 years old and $46.3 \%$ had been working with their organization between six and ten years. Sixty-three supervisors completed the behavioural ratings in which each supervisor rated between one and three subordinates (median $=2.0)$. One-way ANOVA testing for variations in supervisor ratings of performance dimensions (e.g. altruism,
$\mathrm{F}=0.42, \mathrm{~ns}$; civic virtue behaviour, $\mathrm{F}=1.32, \mathrm{~ns}$; and in-role performance, $\mathrm{F}=0.84$ ) and self-rated LMX ratings $(\mathrm{F}=1.28$, ns) across supervisor groups revealed no significant differences.

Sample 3. We recruited MBA students and their immediate supervisors to participate in our research. At time 1 (T1), surveys were distributed to 250 part-time MBA students in three Philippine universities. In particular, they were instructed to pass on a short survey to their immediate supervisor. The questionnaire assessed demographic variables and supervisors' perceptions of LMX with his/her subordinates. We received 200 completed supervisor reports (matched with the ID number of the $200 \mathrm{MBA}$ students), yielding a response rate of $80 \%$. Approximately $53.1 \%$ of the participants were male; $64 \%$ of the supervisors were between 36 and 50 years old; $52 \%$ of the supervisors had been working in their current organization for more than 11 years. At time 2 (T2), six months after, we distributed self-report surveys assessing perceptions of psychological contract breach to the 200 MBA students whose supervisors participated in the first survey. A total of 185 respondents completed the T2 survey for a response rate of $92.3 \%$. At time 3 (T3), one month after $\mathrm{T} 2$ data collection, we administered a self-report survey assessing various employee behaviours to the 185 respondents; we retrieved surveys from 162 participants yielding a response rate of $87.57 \%$.

The three waves of data collection yielded 162 matched T1 supervisor report and T2 and T3 self-report surveys. In order to check for sampling bias, we ran a series of univariate analyses comparing the demographic variables of MBA participants who completed the T2 and T3 surveys. No significant differences were detected between these two groups in terms of gender, age and tenure. Employee participants were evenly distributed in terms of gender (80 males, 82 females); $54 \%$ were between 21 and 30 years old, and $43 \%$ had been working in their current organization between one and five years. Employee participants were employed in a wide variety of occupations, including general management $(23.8 \%)$, customer service $(19 \%)$, accounting and finance $(18.1 \%)$, sales $(13.8 \%)$, research and development $(9.4 \%)$, marketing and 
public relations $(4.6 \%)$, information technology $(3.8 \%)$, manufacturing and production $(3.1 \%)$ and human resources $(4.4 \%)$.

\section{Measures}

Survey questionnaires were prepared in English because this language is considered an official language in the Philippines and is taught to most Filipinos at a young age (Bernardo, 2004). Unless otherwise specified, a seven-point Likert-type response format $(1=$ strongly disagree, $7=$ strongly agree) was used for all measures, with items coded such that a higher score indicated a greater value for the focal construct. To obtain participants' scores on the measures, items within each measure were averaged. The reliability coefficients for the study variables are also reported below.

Psychological contract breach. Employees were instructed to rate the extent to which their psychological contracts have been fulfilled by their organization. We used Robinson and Morrison's (2000) five-item global scale to measure perceptions of contract breach. An example item is 'I felt that my employer has come through in fulfilling the promises made to me when I was hired' (reverse coded). This scale yielded a reliability coefficient of 0.72 for sample 1 and 0.88 for sample 2. Perceptions of psychological contract breach for participants in sample 3 were collected at $\mathrm{T} 2$ and the reliability coefficient for this measure was 0.87 .

Leader-member exchange. LMX data were collected from two distinct sources using the sevenitem scale developed by Graen and Uhl-Bien (1995). In samples 1 and 2, we used employee reports of the quality of their relationship with their respective supervisors. An example item is 'I would characterize my working relationship with my supervisor as extremely effective'. Scale reliability coefficient was 0.74 and 0.92 for samples 1 and 2, respectively. In sample 3, we used supervisor reports of LMX. Specifically, supervisors rated the quality of relationship they have with their respective subordinates. This was measured at T2. An example item is 'I would characterize my working relationship with this employee as extremely effective'. Coefficient alpha of LMX in sample 3 was 0.96.
In-role performance. Williams and Anderson's (1991) four-item scale was used to assess in-role performance in sample 2. Immediate supervisors rated the extent to which their subordinates performed their duties and responsibilities. A sample item is 'This employee fulfils all the responsibilities specified in his/her job description'. This scale obtained a reliability of 0.95 for sample 2. In sample 3, we asked participants to rate their own in-role performance at $\mathrm{T} 3$ using the two-item scale $(\mathrm{r}=0.97, \mathrm{p}<0.001)$ from Ashford and Black (1996).

Organizational citizenship behaviours. Two dimensions of OCB were assessed using the scale developed by Podsakoff et al. (1990). The dimensions were (a) altruism, which involves voluntarily assisting co-workers adjust to their job and effectively manage their work-related problems; and (b) civic virtue behaviour, which refers to active participation in organizational activities, keeping up with the changes affecting the organization, and being concerned with the welfare of the organization and its members. In samples 1 and 2, supervisors were requested to report the extent to which their subordinates engaged in beneficial behaviours directed to their organization and co-workers. Scale reliabilities were altruism (sample 1, $\alpha=0.73$; sample 2, $\alpha=0.89$ ) and civic virtue behaviour (sample 1 , $\alpha=0.72$; sample $2, \alpha=0.80$ ). In sample 3 , participants rated their own altruism $(\alpha=0.81)$ and civic virtue behaviours $(\alpha=0.80)$ at T3.

Control variables. Past research has shown that work attitudes and behaviours can be influenced by demographic characteristics (Mowday, Porter and Steers, 1982). Consistent with past research on psychological contracts, we controlled for gender, age and tenure across the three samples. Tenure was controlled because employees with longer tenure tend to have greater levels of social exchanges with their organization compared to employees with shorter tenure (and corresponding lower levels of social exchanges) who are more likely to exit their organization (Rhoades and Eisenberger, 2002). Gender was controlled to account for the possibility that it influences social exchange relationships (Rhoades and Eisenberger, 2002). Similarly, we acknowledge the possibility that employees may be evaluated differently 
by their immediate supervisors based on their gender. Finally, we controlled for age because there is research evidence to suggest that older employees respond to breach differently from younger employees (Bal et al., 2008).

\section{Results}

The means, standard deviations and zero-order correlations for the study variables are displayed in Table 1. Zero-order correlations were all in the expected direction. Moderated multiple regression (MMR) analyses were conducted to test the interactive effect of breach and LMX on both OCB and in-role performance. Study variables were centred prior to their inclusion in the regression analysis (Aiken and West, 1991). In the first step, demographic characteristics were entered. Independent and moderator variables were entered in step 2, followed by the product term in step 3. MMR analysis tests for the significance of the increment in criterion variance explained by the product term over and above the contribution of the main effects. To fully test for the moderating effects (Aiken and West, 1991), we examined the sign and the significance of the slope of the relationship between psychological contract breach and LMX and the dependent variables at one standard deviation above and one standard deviation below the mean (i.e. each representing low and high levels of LMX).

Sample 1. Table 2 suggests that both psychological contract breach and LMX predicted both types of OCB. The interactive term involving psychological contract breach and LMX accounted for $3 \%$ (i.e. $\delta \mathrm{R}^{2}=0.03, \mathrm{p}<0.05$ ) of the overall variance in altruism. To aid interpretation, we plotted the slopes for high and low levels of LMX. As shown in Figure 1, employees with high LMX, $\mathrm{t}(170)=-2.50, \mathrm{p}<0.05$, demonstrated a sharper drop in their level of altruism as the degree of psychological contract breach

Table 1. Descriptive statistics and zero-order correlations among the study variables

\begin{tabular}{|c|c|c|c|c|c|c|c|c|c|c|}
\hline & Mean & $\mathrm{SD}$ & 1 & 2 & 3 & 4 & 5 & 6 & 7 & 8 \\
\hline \multicolumn{11}{|l|}{ Sample 1} \\
\hline 1. Gender & 1.66 & 0.47 & & & & & & & & \\
\hline 2. Age & 3.21 & 0.99 & -0.03 & & & & & & & \\
\hline 3. Tenure & 2.19 & 0.66 & -0.03 & $0.61^{* *}$ & & & & & & \\
\hline 4. Psychological contract breach & 2.15 & 0.65 & -0.14 & $-0.16^{*}$ & -0.08 & $(0.72)$ & & & & \\
\hline 5. LMX & 5.73 & 0.53 & $0.18^{*}$ & $0.15^{*}$ & $0.15^{*}$ & $-0.46^{* *}$ & $(0.74)$ & & & \\
\hline 6. Supervisor-rated altruism & 5.82 & 0.68 & 0.07 & 0.11 & 0.02 & $-0.21 * *$ & $0.33 * *$ & $(0.74)$ & & \\
\hline 7. Supervisor-rated civic virtue behaviour & 5.79 & 0.67 & 0.11 & 0.10 & $0.16^{*}$ & $-0.31^{* *}$ & $0.32 * *$ & $0.44 * *$ & $(0.72)$ & \\
\hline \multicolumn{11}{|l|}{ Sample 2} \\
\hline 1. Gender & 1.49 & 0.50 & & & & & & & & \\
\hline 2. Age & 2.88 & 1.17 & -0.07 & & & & & & & \\
\hline 3. Tenure & 1.95 & 1.01 & 0.01 & $0.73 * *$ & & & & & & \\
\hline 4. Psychological contract breach & 2.72 & 1.24 & -0.01 & -0.05 & 0.08 & $(0.88)$ & & & & \\
\hline 5. LMX & 5.42 & 0.89 & 0.07 & 0.11 & -0.03 & $-0.65^{* *}$ & $(0.92)$ & & & \\
\hline 6. Supervisor-rated altruism & 5.72 & 0.82 & 0.02 & 0.07 & -0.05 & $-0.55 * *$ & $0.46^{* *}$ & $(0.89)$ & & \\
\hline 7. Supervisor-rated civic virtue behaviour & 5.34 & 0.82 & 0.05 & 0.03 & -0.11 & $-0.24 * *$ & $0.32 * *$ & $0.32 * *$ & $(0.80)$ & \\
\hline 8. Supervisor-rated in-role performance & 5.83 & 0.91 & 0.05 & 0.07 & -0.10 & $-0.60 * *$ & $0.51 * *$ & $0.63 * *$ & $0.54 * *$ & $(0.95)$ \\
\hline \multicolumn{11}{|l|}{ Sample 3} \\
\hline 1. Gender & 1.5 & 0.50 & & & & & & & & \\
\hline 2. Age & 3.83 & 1.77 & $0.18^{*}$ & & & & & & & \\
\hline 3. Tenure & 2.43 & 1.19 & 0.14 & $0.64 * *$ & & & & & & \\
\hline 4. T1 Supervisor-reported LMX & 5.68 & 1.10 & -0.12 & $-0.43 * *$ & $0.35 * *$ & $(0.96)$ & & & & \\
\hline 5. T2 Psychological contract breach & 2.52 & 0.96 & 0.01 & $0.22 * *$ & $0.18^{*}$ & $-0.32 * *$ & $(0.87)$ & & & \\
\hline 6. T3 Self-reported altruism & 5.64 & 1.09 & $-0.17^{*}$ & $-0.29 * *$ & $-0.36^{* *}$ & $0.54 * *$ & $-0.37 * *$ & $(0.80)$ & & \\
\hline 7. T3 Self-reported civic virtue behaviour & 5.36 & 0.93 & -0.08 & $-0.17 *$ & $-0.20^{*}$ & $0.35^{* *}$ & $-0.49^{* *}$ & $0.49 * *$ & $(0.81)$ & \\
\hline 8. T3 Self-reported in-role performance & 5.70 & 1.08 & -0.04 & -0.07 & -0.04 & $0.29 * *$ & $-0.20^{* *}$ & $0.35^{* *}$ & $0.36^{* *}$ & $(0.97)$ \\
\hline
\end{tabular}

${ }^{*} \mathrm{p}<0.05,{ }^{* *} \mathrm{p}<0.01$ 
Table 2. Hierarchical moderated regression for altruism and civic virtue behaviour in sample 1

\begin{tabular}{lcc}
\hline Variables & $\begin{array}{c}\text { Supervisor- } \\
\text { rated altruism }\end{array}$ & $\begin{array}{c}\text { Supervisor-rated civic } \\
\text { virtue behaviour }\end{array}$ \\
\cline { 2 - 3 } & $\beta$ & $\beta$ \\
\hline Step 1 & & \\
Gender & 0.07 & 0.12 \\
Age & 0.16 & 0.01 \\
Tenure & 0.07 & 0.15 \\
Step R & 0.022 & 0.04 \\
Step 2 & & \\
Psychological & $-0.19^{*}$ & $-0.20^{*}$ \\
contract breach (PCB) & & \\
LMX & $0.31^{* *}$ & $0.22^{* *}$ \\
Step R ${ }^{2}$ & $0.11^{* * *}$ & \\
Step $\Delta \mathrm{R}^{2}$ & $0.13^{* * *}$ & $0.15^{* * *}$ \\
Step 3 & & \\
PCB $\times$ LMX & $-0.16^{*}$ & $-0.12^{+}$ \\
Step R ${ }^{2}$ & $0.03^{*}$ & $0.02^{+}$ \\
Step $\Delta \mathrm{R}^{2}$ & $0.16^{* *}$ & $0.17^{+*}$ \\
\hline
\end{tabular}

${ }^{+} \mathrm{p}<0.10 ;{ }^{*} \mathrm{p}<0.05 ;{ }^{* *} \mathrm{p}<0.01$.

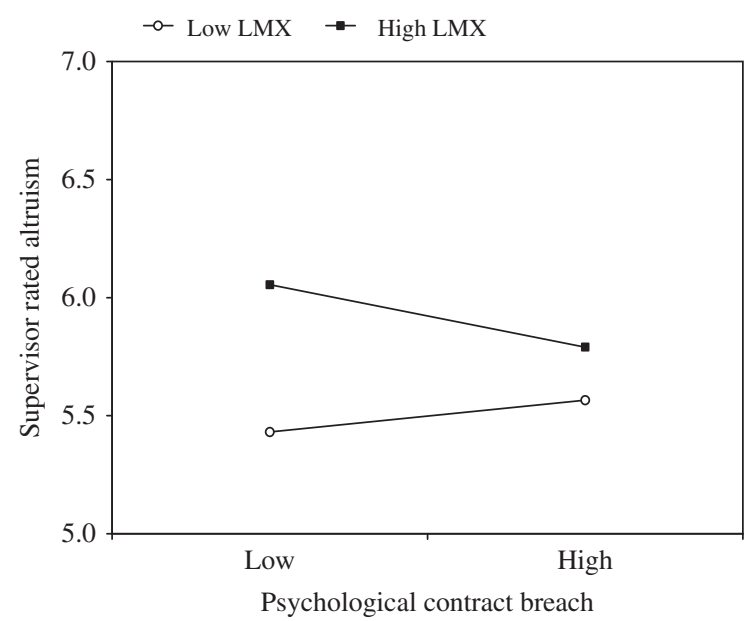

Figure 1. The interaction between psychological contract breach and LMX on supervisor-rated altruism in sample 1.

increased, compared with those with low LMX, $\mathrm{t}(170)=1.27$, ns. Along similar lines, the interactive term contributed marginal variance in explaining civic virtue behaviour, $\Delta \mathrm{R}^{2}=0.02$, $\mathrm{p}<0.08$. The slope for high LMX was significant whereas the slope for low LMX was not. Figure 2 shows that breach had stronger negative relationships with civic virtue behaviour for those employees with high levels of LMX, $\mathrm{t}(70)=$ $-6.52, \mathrm{p}<0.01$, compared with those with low levels of LMX, $\mathrm{t}(170)=-1.85$, ns. Hypothesis $2 \mathrm{~b}$ was supported.

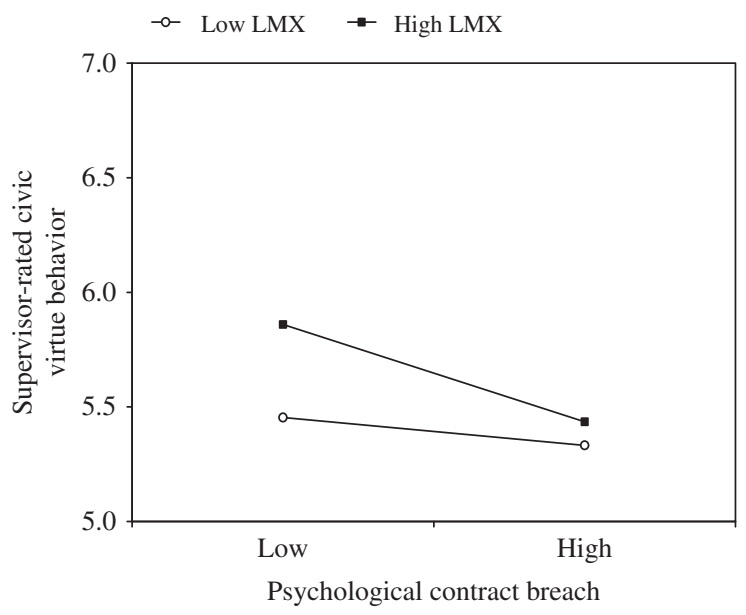

Figure 2. The interaction between psychological contract breach and LMX on supervisor-rated civic virtue behaviour in sample 1.

Sample 2. Results in Table 3 showed that both psychological contract breach and LMX predicted in-role performance and both types of OCB. Entry of the breach $\times$ LMX product term explained incremental variance in explaining altruism $\left(\Delta \mathrm{R}^{2}=0.05, \mathrm{p}<0.01\right)$, civic virtue behaviour $\left(\Delta \mathrm{R}^{2}=0.08, \mathrm{p}<0.01\right)$ and in-role performance $\left(\Delta \mathrm{R}^{2}=0.06, \mathrm{p}<0.01\right)$. Supplementary analysis suggests that slopes representing low, $\mathrm{t}(133)=$ $-2.34, \quad \mathrm{p}<0.01$, and high, $\mathrm{t}(133)=-5.45$, $\mathrm{p}<0.01$, levels of LMX were significant for supervisor-rated altruism. Along similar lines, the slopes representing low, $\mathrm{t}(133)=-2.67, \mathrm{p}<0.01$, and high, $\mathrm{t}(133)=-6.56, \mathrm{p}<0.01$, levels of LMX were significant for supervisor-rated in-role performance. Inspection of Figures 3 and 4 and the results of the $t$ tests reveal a stronger negative relationship in the high LMX condition. A similar pattern of results emerged for supervisor-rated civic virtue behaviour. Figure 5 suggests stronger negative effects of psychological contract breach on supervisor-rated civic virtue behaviour under conditions of high LMX, $\mathrm{t}(133)=-2.1, \mathrm{p}<0.05$, as opposed to low LMX, $\mathrm{t}(133)=1.40$, ns. Overall, Hypotheses $1 \mathrm{~b}$ and $2 \mathrm{~b}$ representing the betrayal perspective were supported.

Sample 3. Results in Table 4 showed that T1 supervisor-rated LMX and T2 employee perceptions of breach were associated withT3 employee reports of altruism, civic virtue behaviour and inrole performance. Entry of the interactive term explained additional variance in T3 altruism, 
Table 3. Hierarchical moderated regression for altruism, civic virtue behaviour and in-role performance in sample 2

\begin{tabular}{lccc}
\hline Variables & $\begin{array}{c}\text { Supervisor-rated } \\
\text { altruism }\end{array}$ & $\begin{array}{c}\text { Supervisor-rated civic virtue } \\
\text { behaviour }\end{array}$ & $\begin{array}{c}\text { Supervisor-rated in-role } \\
\text { performance }\end{array}$ \\
\cline { 2 - 4 } & $\beta$ & $\beta$ & $\beta$ \\
\hline Step 1 & & & 0.07 \\
Gender & 0.03 & $0.24^{*}$ & $0.27^{*}$ \\
Age & 0.18 & $-0.29^{*}$ & $-0.32^{* *}$ \\
Tenure & -0.19 & 0.02 & 0.05 \\
Step R & 0.022 & & $-0.07^{* *}$ \\
Step 2 & & $0.27^{*}$ & $0.20^{*}$ \\
Psychological contract breach (PCB) & $-0.43^{* *}$ & $0.08^{* *}$ & $0.35^{* *}$ \\
LMX & $0.19^{*}$ & $0.13^{* * *}$ & $0.40^{* * *}$ \\
Step R & $0.29^{* *}$ & & $-0.28^{* *}$ \\
Step $\Delta \mathrm{R}^{2}$ & $0.31^{* * *}$ & $-0.32^{* *}$ & $0.06^{* *}$ \\
Step 3 & & $0.08^{* * *}$ & $0.46^{* *}$ \\
$\Delta \mathrm{PCB} \times$ LMX & $-0.25^{* *}$ & $0.21^{* * *}$ & \\
$\Delta$ Step R & $0.05^{* * *}$ & $0.36^{* * *}$ & \\
$\Delta$ Step $\Delta \mathrm{R}^{2}$ & & & \\
\hline
\end{tabular}

${ }^{*} \mathrm{p}<0.05 ; * * \mathrm{p}<0.01$.

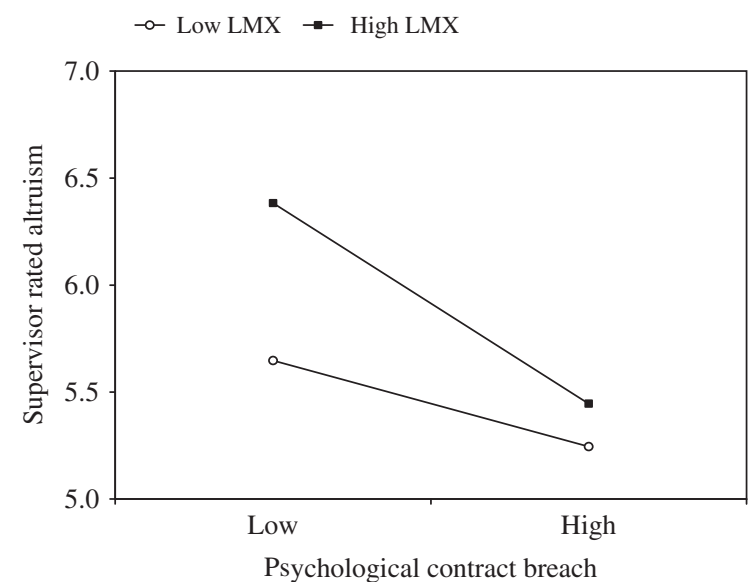

Figure 3. The interaction between psychological contract breach and LMX on supervisor-rated altruism in sample 2.

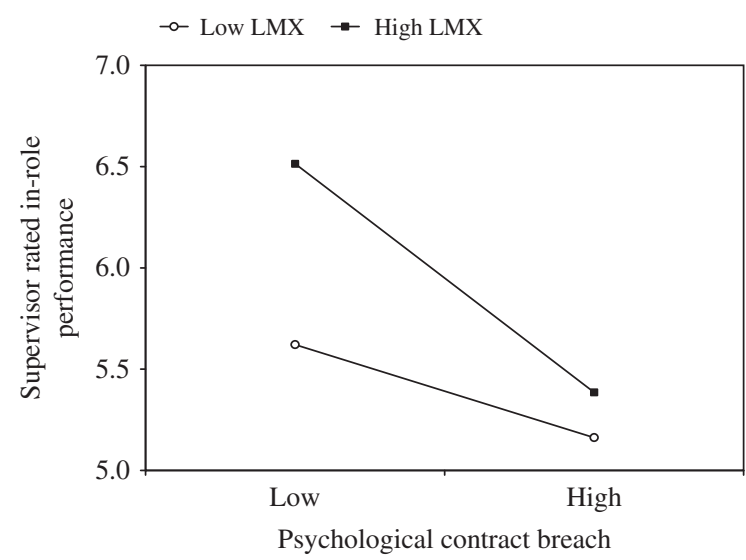

Figure 4. The interaction between psychological contract breach and LMX on supervisor-rated in-role performance in sample 2.

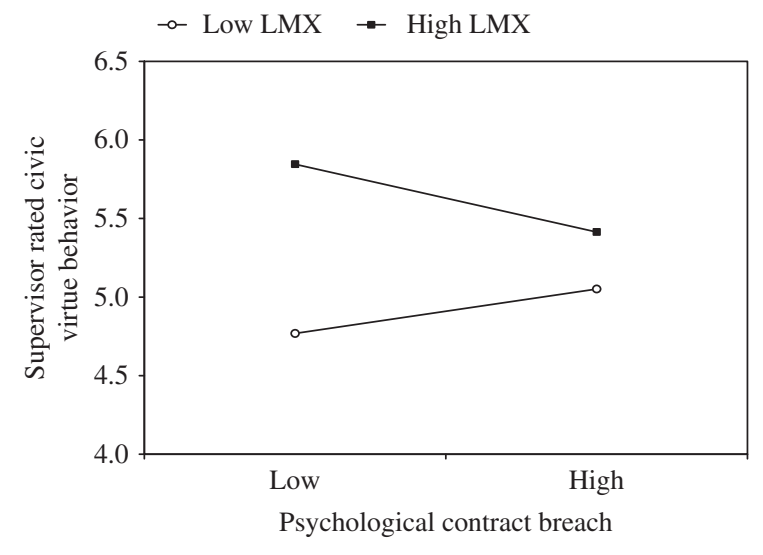

Figure 5. The interaction between psychological contract breach and LMX on supervisor-rated civic virtue behaviour in sample 2.

civic virtue behaviour and in-role performance. Simple slope analyses suggest that under high levels of T1 supervisor-rated LMX there was a stronger negative relationship between $\mathrm{T} 2$ breach and $\mathrm{T} 3$ altruism, $\mathrm{t}(155)=-6.77, \mathrm{p}<0.01$, compared with low levels of T1 supervisor-rated LMX, $\mathrm{t}(155)=0.13$, ns (see Figure 6). As shown in Figure 7, employees with high levels of supervisor-rated LMX demonstrated a sharper drop in their levels of self-reported civic virtue behaviour at $\mathrm{T} 3, \mathrm{t}(155)=-6.13, \mathrm{p}<0.01$, as the degree of T2 psychological contract breach increased, compared to those with low supervisor-rated $\mathrm{LMX}, \mathrm{t}(155)=-2.29, \quad \mathrm{p}<0.05$. 
Table 4. Hierarchical moderated regression for altruism, civic virtue behaviour and in-role performance in sample 3

\begin{tabular}{lccc}
\hline Variables & $\begin{array}{c}\text { T3 Self-reported } \\
\text { altruism }\end{array}$ & $\begin{array}{c}\text { T3 Self-reported civic virtue } \\
\text { behaviour }\end{array}$ & $\begin{array}{c}\text { T3 Self-reported in-role } \\
\text { performance }\end{array}$ \\
\cline { 2 - 4 } & $\beta$ & $\beta$ & $\beta$ \\
\hline Step 1 & & & -0.10 \\
Gender & -0.03 & -0.04 & -0.10 \\
Age & -0.07 & -0.08 & $-0.28^{* *}$ \\
Tenure & 0.01 & -0.14 & $0.15^{* *}$ \\
Step R & 0.01 & 0.04 & $-0.22^{* *}$ \\
Step 2 & & $-0.42^{* *}$ & $0.44^{* *}$ \\
T2 Psychological contract breach (PCB) & $-0.16^{*}$ & $0.21^{* *}$ & $0.38^{* *}$ \\
T1 Supervisor-rated LMX & $0.29^{* *}$ & $0.28^{* *}$ & $0.24^{* *}$ \\
Step R & $0.11^{* *}$ & $0.04^{* *}$ & $-0.20^{* *}$ \\
Step $\Delta \mathrm{R}^{2}$ & $0.11^{* *}$ & $-0.16^{*}$ & $0.42^{* *}$ \\
Step 3 & & $0.30^{* *}$ & $0.04^{* *}$ \\
PCB $\times$ LMX & $-0.20^{*}$ & $0.02^{* *}$ & \\
Step R & $0.15^{* * *}$ & $0.03^{* * *}$ & \\
Step $\Delta \mathrm{R}^{2}$ & & & \\
\hline
\end{tabular}

$* \mathrm{p}<0.05 ; * \mathrm{p}<0.01$

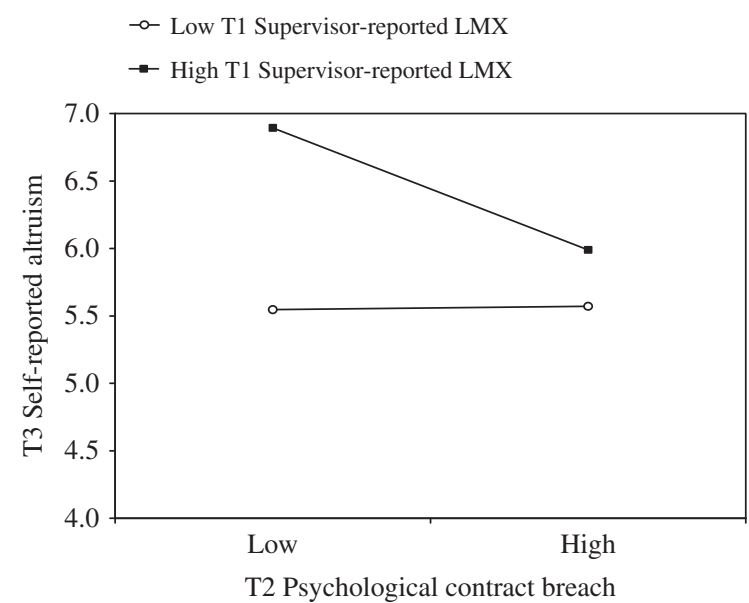

Figure6. The interaction between T2 psychological contract breach and T1 LMX on altruism in sample 3.

Finally, Figure 8 shows that under high levels of supervisor-rated LMX T2 breach had a stronger negative association with $\mathrm{T} 3$ in-role performance, $\mathrm{t}(155)=-3.08, \mathrm{p}<0.01$, compared to those with low supervisor-rated LMX, $\mathrm{t}(155)=-0.52$, ns. In sum, Hypotheses $1 \mathrm{~b}$ and $2 \mathrm{~b}$ representing the betrayal perspective were supported.

\section{Discussion}

The purpose of the study was to investigate the moderating role of LMX between psychological contract breach and employee performance. Our

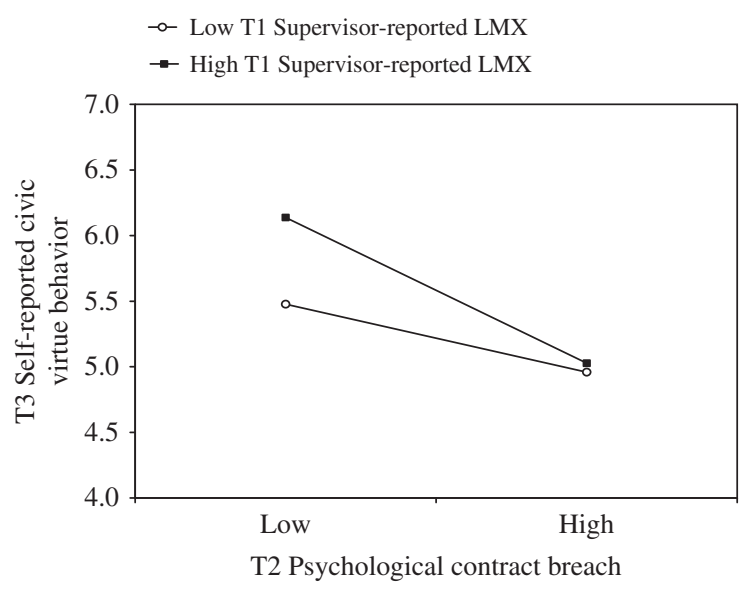

Figure 7. The interaction between T2 psychological contract breach and T1 LMX on civic virtue behaviour in sample 3.

results showed that LMX emerged as a significant moderator between breach and in-role performance and OCB dimensions (i.e. altruism and civic virtue behaviour). Specifically, under high conditions of LMX, employees decreased their OCB and in-role performance as the level of psychological contract breach increased.

There are two possible explanations for these findings. First, consistent with the betrayal framework, employees with high LMX demonstrated a sharp drop in their altruism and civic virtue behaviour (samples 1 and 2) and in-role performance (sample 2) as the degree of contract breach increased. The betrayal interpretation 


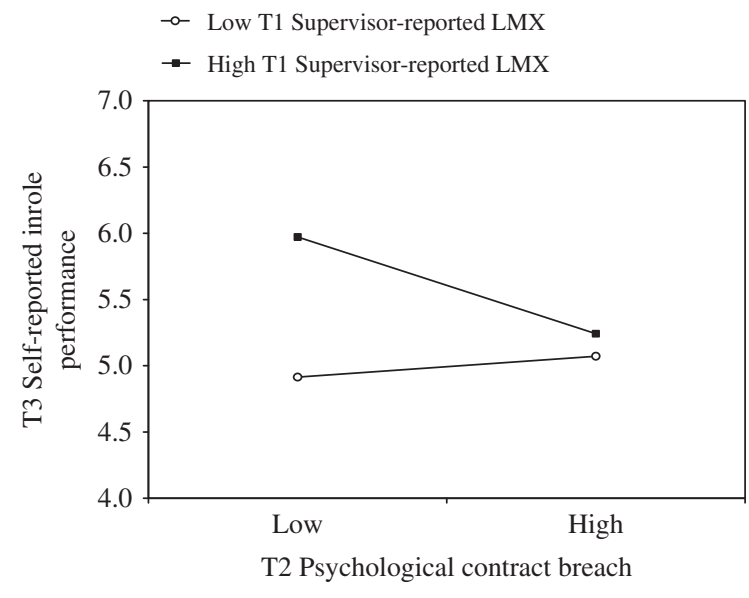

Figure 8. The interaction between T2 psychological contract breach and T1 LMX on in-role performance in sample 3.

assumes that the high LMX relationship existed prior to the experience of breach. The longitudinal nature of the data collected in sample 3 provides stronger empirical evidence that a favourable relationship with the supervisor seems to result in worse outcomes in the event of a contractual transgression. Betrayal often results in negative emotions and behaviours as a consequence of an erosion of trust and relational dissolution (Reina and Reina, 1999). In consonance with the betrayal framework explanation, research on social support has noted the possibility of a 'reverse buffering' effect (Kaufman and Beehr, 1986; Kobasa and Puccetti, 1983). Kaufman and Beehr identified two conditions to further explain this phenomenon: (a) the source of support is the cause of stress and (b) supportive communication provided by the supervisor may even aggravate the perceived stress because the supervisor may potentially trivialize the stressful experience of the employee. As high LMX relationships involve mutual trust, support and obligation, an important aspect of the relationship has to do with the supervisor's obligation to provide affective and resource-based support for his/her constituents. Perceptions of breach do not fit with this expectation and the supportive relationship becomes a context that compounds the problematic experience of breach.

Second, the interaction effects may also be explained in accordance with the expectancyviolation hypothesis which suggests that 'people react more strongly to another party's actions that violate their previous expectations of how the other party is likely to behave' (Brockner, Tyler and Cooper-Schneider, 1992, p. 258). Our results are consistent with previous studies where employees with more favourable attitudes had a stronger negative relationship with outcome variables as compared to those with less favourable attitudes (Brockner, Tyler and CooperSchneider, 1992; George, 2003). For example, Brockner and his colleagues found that individuals with relatively high prior commitment reacted more negatively to unfair treatment than individuals with low prior commitment. Similarly, George found that the impact of employee externalization (or outsourcing) on work attitudes of permanent staff was more negative for employees who had high job security than those with low job security. A study by Restubog and Bordia (2006) also revealed stronger negative effects of psychological contract breach on civic virtue behaviour for those employees with high levels of workplace familism (i.e. extent to which employees perceive the supervisor as a parental figure and relate to them in ways similar to a family) compared to those with low levels of workplace familism. In the context of our research, employees reporting high LMX have an expectation that they will be helped and bailed out against any form of negative employment experiences. Breach of the psychological contract can be conceived as a form of injustice (Morrison and Robinson, 1997). As a consequence, this results in anger because the leader/supervisor whom employees expected to protect them failed to fulfil his/her role.

\section{Theoretical implications}

An important contribution of our paper pertains to the use of two competing perspectives in explaining the moderating effects of LMX. While many previous studies have typically conceptualized LMX within a social support framework (e.g. Erdogan, Kraimer and Liden, 2004; O'Driscoll et al., 2003) the present study found support for the betrayal perspective. It appears that when employees have a high quality of relationship with their supervisors, employees may expect protection from psychological contract breach. In other words, a high quality relationship imposes further expectations on the leader. Our findings provide a new insight suggesting that if 
psychological contract breach is perceived then the behavioural consequences will be more severe under high conditions of LMX. However, we should also acknowledge the fact that there is a strong negative relationship between breach and LMX indicating that higher LMX employees do perceive lower levels of breach. Clearly more research examining the underlying reasons for this effect is warranted. The results may also suggest a boundary condition in the buffering role of LMX. That is, LMX appears to be effective in reducing the negative consequences that arise from low levels of breach. However, its 'alleviating effects' seem to weaken as the magnitude of breach increases. Although our study found support for a betrayal explanation, future research needs to closely examine the underlying reasons for this effect.

Another theoretical implication of our research concerns the different rating sources of LMX. Leader and member ratings are proposed to be congruent, with the level of agreement between the two perspectives serving as an indicator of the quality of the exchange (Graen and Uhl-Bien, 1995). Traditionally, LMX research has focused on the leader-member relationship from the perspective of the member alone (LMX-m). However, this often neglects the other side of the dyad - the view of the relationship from the perspective of the leader (LMX-1). As LMX theory is explicitly dyadic in nature, we measured the leader-member relationship from the perspective of both the subordinate (samples 1 and 2) and the leader (sample 3). We found consistent evidence for the betrayal effect from both sources of LMX ratings.

Finally, our use of a Philippine sample may also have implications in our results. The Philippine culture, being collectivistic, emphasizes smooth interpersonal relationships (Restubog and Bordia, 2006) and unconditional benevolence in exchange relationships (Leung, 2001). In contrast to western contexts, employment relationships in developing countries are heavily grounded in interpersonal relationships and community sharing (Hofstede, 1980). For example, despite the strong influence of American management practices, Philippine organizations have retained a familial nature in the way employees relate with their employer (Restubog and Bordia, 2006). In the Philippines, there is also a strong regard to what has been termed palabra de honor (word of honour) or spoken assurance which creates a commitment or an expectation between parties (Church, 1987). The fulfilment of promises leads a person to develop commitment. There is evidence to suggest that promises in some cultures may be interpreted as binding (Rousseau and Schalk, 2000) and may also serve as a building block of psychological contracts (Rousseau, 2001). Failure on the part of the other party to fulfil its palabra de honor suggests that the other party does not have honour and thus cannot be trusted. Overall, these value orientations are likely to shape employment relationships and psychological contracts in the Philippine context.

\section{Limitations and strengths}

There are number of limitations that need to be acknowledged. First, employee performance was limited as it only tapped OCBs and in-role performance. We recommend that future research examine a broader range of outcome variables to assess the degree to which the relationships we observed would also generalize to other behavioural outcomes such as actual turnover, anti-role behaviours, job embeddedness and voice. Future research can also incorporate emotional experiences of employees as another potential mediating variable between breach, supervisor-subordinate interactions and employee behaviours. For example, several researchers have acknowledged the role of emotions in leadership research (e.g. Rafferty and Griffin, 2004; Tse, Dasborough and Ashkanasy, 2008).

A second limitation is that betrayal perceptions may rely upon attributions of blame. As such, we did not explicitly measure attributions of blame. Future research should seek to understand the heuristics used by employees in the attribution process. A thorough examination of these factors may provide a detailed analysis to explain the role of causal attributions in the psychological contract-making (Kiewitz et al., 2009). Similarly, psychological contract theory suggests that, even though a psychological contract originates with the organization, the promised obligations on behalf of the organization may be arranged with the supervisor (Rousseau, 1995). Thus, apart from the generalized expectations arising from the organization, employees are likely to develop psychological contract with the supervisor (Bordia 
et al., 2008b). Because the resulting attitudinal and behavioural consequences of breach are largely influenced by how perceived transgressions are interpreted (Morrison and Robinson, 1997), future research should use specific referents (organization versus supervisor) to help delineate the source of breach as well as uncover differential outcomes as a result of a particular source of breach. For example, breach associated with the supervisor may result in reduced in-role performance and OCBs directed to co-workers while breach associated with the organization may result in reduced OCBs directed to the organization.

Third, we were unable to measure certain contract dimensions which are important for understanding the negative ramifications of breach. Researchers have noted that the resulting outcomes of breach may be dependent on the type of psychological contract in effect (Morrison and Robinson, 1997; Restubog et al., 2008). For example, using the group value model, Restubog and his colleagues found that relational breach (i.e. long-term and socio-emotional aspects of the employment relationship) tend to send stronger symbolic messages about the quality of the relationship between the individual and the group than would breaches of transactional contracts (i.e. more specific, short-term and instrumental aspects of the employment relationship). A consideration of this contract dimension will enable us to better understand what type of psychological contract breach is destructive to employee well-being and performance.

Finally, a methodological limitation concerns the design that we have used in sample 3 . Although we have employed a longitudinal design, we were unable to control for base line measures of the outcome variables (i.e. selfreported altruism, civic virtue behaviour and inrole performance). Thus, one cannot rule out the possibility of reverse causation (Collins, 2006).

Our study has several methodological strengths. First, utilization of independent assessments of behaviour and quality of relationship addresses the concern of common method variance and probably provides more reliable results than using self-reported measures. Second, the convergence of moderation effects obtained across the three independent samples provides greater confidence in our findings. Indeed, Popper (1959) noted the value of multiple study designs: 'only by such repetitions can we convince ourselves that we are not dealing with a mere isolated coincidence' (p. 45). Thus, the replication of results across several studies is critical to generalization (Lindsay and Ehrenberg, 1993).

\section{Practical implications}

Our research suggests that while high levels of LMX tend to be associated with low levels of psychological contract breach, the negative ramifications of breach under high conditions of LMX tend to be greater. This clearly suggests the salient role of supervisor-employee relationships in predicting behavioural responses to breach, possibly because a perception of breach may signal to the employee that the leader does not respect his/her rights and does not value their relationship. While organizations should promote a high quality LMX, they must also be mindful that this is likely to create and impose greater expectations on behalf of the employees. This in turn may result in detrimental outcomes if these commitments are not adequately maintained. To minimize these negative outcomes, we recommend that managers investigate the commitments they may have unknowingly conveyed to their employees and strive to fulfil these, if possible. Similarly, organizations can use upward communication strategies such as employee feedback systems and exit interviews to ascertain what their employees expect. These strategies may help organizations fulfil psychological contracts and better manage the aftermath of breach.

\section{References}

Aiken, L. S. and S. G. West (1991). Multiple Regression: Testing and Interpreting Interactions. Newbury Park, CA: Sage.

Armstrong, J. S., R. J. Brodie and A. G. Parsons (2001). 'Hypotheses in marketing science: literature review and publication audit', Marketing Letters, 12, pp. 171-187.

Ashford, S. and J. S. Black (1996). 'Proactivity during organizational entry: the role of desire for control', Journal of Applied Psychology, 81, pp. 199-214.

Bal, P. M., A. De Lange, P. Jansen and M. Van Der Velde (2008). 'Psychological contract breach and job attitudes: a meta-analysis of age as a moderator', Journal of Vocational Behavior, 72, pp. 143-158.

Beehr, T., S. Farmer, S. Glazer, D. Gudanowski and V. Nair (2003). 'The enigma of social support and occupational stress: source congruence and gender role effect', Journal of Occupational Health Psychology, 8, pp. 220-231. 
Bernardo, A. B. I. (2004). 'McKinley's questionable bequest: over 100 years of English in Philippine education', World Englishes, 23, pp. 17-31.

Blau, P. M. (1964). Exchange and Power in Social Life. New York: Wiley.

Bliese, P. D. (2000). 'Within-group agreement, non-independence, and reliability: implications for data aggregation and analyses'. In K. J. Klein and S. W. J. Kozlowski (eds), Multilevel Theory, Research, and Methods in Organizations: Foundations, Extensions, and New Directions, pp. 349-381. San Francisco, CA: Jossey-Bass.

Bordia, P., S. L. D. Restubog and R. L. Tang (2008a). 'When employees strike back: investigating mediating mechanisms between psychological contract breach and workplace deviance', Journal of Applied Psychology, 93, pp. 1104-1117.

Bordia, P., S. L. D. Restubog, S. Bordia and R. L. Tang (2008b). 'Breach begets breach: a trickle-down effect of psychological contract breach on customer service'. Paper presented at the 68th Annual Meeting of the Academy of Management, Anaheim, CA.

Brockner, J., T. R. Tyler and R. Cooper-Schneider (1992). 'The influence of prior commitment to an institution on reactions to perceived unfairness: the higher they are, the harder they fall', Administrative Science Quarterly, 37, pp. 241-261.

Chamberlin, T. C. (1890). 'The method of multiple working hypotheses', Science, 15, pp. 92-96.

Church, A. T. (1987). 'Personality research in a non-western culture: the Philippines', Psychological Bulletin, 102, pp. 272292.

Cohen, S. and T. A. Wills (1985). 'Stress, social support and the buffering hypothesis', Psychological Bulletin, 98, pp. 310357.

Collins, L. M. (2006). 'Analysis of longitudinal data: the integration of theoretical model, temporal design, and statistical model', Annual Review of Psychology, 57, pp. 505-528.

Couch, L. L., W. H. Jones and D. S. Moore (1999). 'Buffering the effects of betrayal: the role of apology'. In J. M. Adam and W. H. Jones (eds), Handbook of Interpersonal Commitment and Relationship Stability, pp. 449-467. New York: Kluwer Academic.

Dansereau, F., G. B. Graen and W. Haga (1975). 'A vertical dyad linkage approach to leadership to formal organizations', Organizational Behavior and Human Performance, 13, pp. $46-78$.

Deery, S. J., R. D. Iverson and J. T. Walsh (2006). 'Toward a better understanding of psychological contract breach: a study of customer service employees', Journal of Applied Psychology, 91, pp. 166-175.

Elangovan, A. R. and D. L. Shapiro (1998). 'Betrayal of trust in organizations', Academy of Management Review, 23, pp. 547566.

Erdogan, B., M. L. Kraimer and R. Liden (2004). 'Work value congruence and intrinsic career success: the compensatory roles of leader-member exchange and perceived organizational support', Personnel Psychology, 57, pp. 305332.

Festinger, L. (1957). A Theory of Cognitive Dissonance. Stanford, CA: Stanford University Press.

George, E. (2003). 'External solutions and internal problems: the effects of employment externalization on internal workers' attitudes', Organization Science, 14, pp. 386-402.
Gouldner, A. W. (1960). 'The norm of reciprocity', American Sociological Review, 25, pp. 165-167.

Graen, G. B. and M. Uhl-Bien (1995). 'Relationship-based approach to leadership: development of leader-member exchange (LMX) theory of leadership over 25 years: applying a multi-level multi-domain perspective', Leadership Quarterly, 6, pp. 219-247.

Harris, K. J. and K. M. Kacmar (2006). 'Too much of a good thing: the curvilinear effect of leader-member exchange on stress', Journal of Social Psychology, 146, pp. 65-84.

Harrison, D., D. Newman and P. Roth (2006). 'How important are job attitudes? Meta-analytic comparisons for integrative behavioral outcomes and time sequences', Academy of Management Journal, 49, pp. 305-326.

Hofstede, G. (1980). 'Motivation, leadership, and organization: do American theories apply abroad?', Organizational Dynamics, 9, pp. 42-63.

Kaufmann, G. M. and T. A. Beehr (1986). 'Interactions between job stressors and social support: some counterintuitive results', Journal of Applied Psychology, 71, pp. 522526.

Kiewitz, C., S. L. D. Restubog, T. Zagenczyk and W. H. Hochwarter (2009). 'The interactive effects of psychological contract breach and organizational politics on perceived organizational support: evidence from two longitudinal studies', Journal of Management Studies, 46, pp. 806-834.

Kobasa, S. C. and M. C. Puccetti (1983). 'Personality and social resources in stress resistance', Journal of Personality and Social Psychology, 45, pp. 839-850.

Leung, K. (2001). 'Different carrots for different rabbits: effects of individualism collectivism and power distance on work motivation'. In M. Erez, U. Kleinbeck, H. Thierry (eds), Work motivation in the Context of a Globalizing Economy, pp. 329-340. Mahwah, NJ: Lawrence Erlbaum.

Lindsay, R. and A. Ehrenberg (1993). 'The design of replicated studies', American Statistician, 47, pp. 217-228.

Major, B., J. Zubek, M. Cooper, C. Cozzarelli and C. Richards (1997). 'Mixed messages: implications of social conflict and social support within close relationships for adjustment to a stressful life event', Journal of Personality and Social Psychology, 72, pp. 1349-1363.

Martin, R., G. Thomas, K. Charles, O. Epitropaki and R. McNamara (2005). 'The role of leader-member exchanges in mediating the relationship between locus of control and work reactions', Journal of Occupational and Organizational Psychology, 78, pp. 141-147.

Maslyn, J. and M. Uhl-Bien (2001). 'Leader-member exchange and its dimensions: effects of self-effort and other's effort on relationship quality', Journal of Applied Psychology, 86, pp. 697-708.

Morrison, E. W. and S. L. Robinson (1997). 'When employees feel betrayed: a model of how psychological contract develops', Academy of Management Review, 22, pp. 226-256.

Mowday, R., L. Porter and R. Steers (1982). EmployeeOrganization Linkages: The Psychology of Commitment, Absenteeism, and Turnover. New York: Academic Press.

O'Driscoll, M. P., S. Poelmans, P. E. Spector, T. Kalliath, T. D. Allen, C. L. Cooper and J. I. Sanchez (2003). 'Familyresponsive interventions, perceived organizational and supervisor support, work-family conflict, and psychological strain', International Journal of Stress Management, 10, pp. 326-344. 
Podsakoff, P. M., S. B. MacKenzie, R. H. Moorman and R. Fetter (1990). 'Transformational leader behaviors and their effects on followers' trust in leader, satisfaction, and organizational citizenship behaviors', Leadership Quarterly, 1, pp. 107-142.

Podsakoff, P. M., S. B. MacKenzie, J. B. Paine and D. G. Bachrach (2000). 'Organizational citizenship behaviors: a critical review of the theoretical and empirical literature and suggestions for future research', Journal of Management, 26, pp. 513-563.

Popper, K. (1959). The Logic of Scientific Discovery. New York: Basic Books.

Rafferty, A. E. and M. A. Griffin (2004). 'Dimensions of transformational leadership: conceptual and empirical extensions', Leadership Quarterly, 15, pp. 329-354.

Reina, D. S. and M. L. Reina (1999). Trust and Betrayal in the Workplace: Building Relationships in your Organization. San Francisco, CA: Berrett-Koehler.

Restubog, S. L. D. and P. Bordia (2006). 'Workplace familism and psychological contract breach in the Philippines', Applied Psychology: An International Review, 55, pp. 563-585.

Restubog, S. L. D., P. Bordia and R. L. Tang (2006). 'Effects of psychological contract breach on performance of IT employees: the mediating role of affective commitment', Journal of Occupational and Organizational Psychology, 79, pp. 299-306.

Restubog, S. L. D., M. J. Hornsey, P. Bordia and S. Esposo (2008). 'Effects of psychological contract breach on organizational citizenship behavior: insights from the group value model', Journal of Management Studies, 45, pp. 13771400.

Rhoades, L. and R. Eisenberger (2002). 'Perceived organizational support: a review of the literature', Journal of Applied Psychology, 87, pp. 698-714.

Robinson, S. L. (1996). 'Trust and breach of psychological contract', Administrative Science Quarterly, 41, pp. 574-599.

Robinson, S. L. and E. W. Morrison (2000). 'The development of psychological contract breach and violation: a longitudinal study', Journal of Organizational Behavior, 21, pp. $525-546$.

Robinson, S. L. and D. M. Rousseau (1994). 'Violating the psychological contract: not the exception but the norm', Journal of Organizational Behavior, 15, pp. 245-259.

Rousseau, D. M. (1995). Psychological Contracts in Organizations: Understanding Written and Unwritten Agreements. Thousand Oaks, CA: Sage.
Rousseau, D. M. (2001). 'Schema, promise and mutuality: the building blocks of the psychological contract', Journal of Occupational and Organizational Psychology, 74, pp. 511-541.

Rousseau, D. M. and M. M. Greller (1994). 'Human resource practices: administrative contract makers', Human Resource Management, 33, pp. 384-401.

Rousseau, D. M. and R. Schalk (2000). Psychological Contracts in Employment: Cross-National Perspectives. Thousand Oaks, CA: Sage.

Shore, L. M. and L. E. Tetrick (1994). 'The psychological contract as an explanatory framework in the employment relationship'. In C. L. Cooper and D. M. Rousseau (eds), Trends in Organizational Behavior, pp. 91-103. New York: Wiley.

Sias, P. M., R. G. Heath, T. Perry, D. Silva and B. Fix (2004). 'Narratives of workplace friendship deterioration', Journal of Social and Personal Relationships, 21, pp. 321-340.

Tierney, P., T. Bauer and R. E. Potter (2002). 'Extra-role behavior among Mexican employees: the impact of LMX, group acceptance, and job attitudes', International Journal of Selection and Assessment, 10, pp. 292-303.

Tse, H. M., M. T. Dasborough and N. M. Ashkanasy (2008). 'A multi-level analysis of team climate and interpersonal exchange relationships at work', Leadership Quarterly, 19, pp. 195-211.

Turnipseed, D. L. and A. Rassuli (2005). 'Performance perceptions of organizational citizenship behaviours at work: a bi-level study among managers and employees', British Journal of Management, 16, pp. 231-244.

Turnley, W. H. and D. C. Feldman (1998). 'Psychological contract violations during organizational restructuring', $\mathrm{Hu}$ man Resource Management, 37, pp. 71-83.

Viswesvaran, C., J. I. Sanchez and J. Fisher (1999). 'The role of social support in the process of work stress: a meta-analysis', Journal of Vocational Behavior, 54, pp. 314-334.

Williams, L. J. and S. E. Anderson (1991). 'Job satisfaction and organizational commitment as predictors of organizational citizenship and in-role behaviors', Journal of Management, 17, pp. 601-617.

Zagenczyk, T. J., R. Gibney, C. Kiewitz and S. L. D. Restubog (2009). 'Mentors, supervisors, and role models: do they reduce the effects of psychological contract breach?', Human Resource Management Journal, 19, pp. 237-259.

Zhao, H., S. J. Wayne, B. C. Glibkowski and J. Bravo (2007). 'The impact of psychological contract breach on workrelated outcomes: a meta-analysis', Personnel Psychology, 60, pp. 647-680. 
Simon Lloyd D. Restubog is a Senior Lecturer in Organizational Behavior in the Australian School of Business at the University of New South Wales, Sydney, Australia. His research focuses on antecedents and maintenance of psychological contracts, workplace deviance and cross-cultural organizational behaviour. His research has been published or is forthcoming in leading applied psychology and management journals such as Journal of Applied Psychology, Journal of Management, Journal of Management Studies, Journal of Cross Cultural Psychology, Journal of Occupational Health Psychology, Journal of Occupational and Organizational Psychology and British Journal of Management.

Prashant Bordia is Professor of Management at the University of South Australia, Adelaide, Australia. His research interests include rumour management, psychological contracts and organizational change. His research has been published in the Academy of Management Journal, Journal of Applied Psychology, Organizational Behavior and Human Decision Processes, Journal of Management Studies and Human Communication Research. He is co-author of Rumor Psychology: Social and Organizational Approaches published by the American Psychological Association.

Robert L. Tang is a Vice President for Academic Affairs and teaches in the School of Management and Information Technology at De La Salle University-College of Saint Benilde, Manila, Philippines. His research focuses on psychological contracts and human resource management practices. His research has been published in Journal of Applied Psychology, Journal of Occupational and Organizational Psychology, Applied Psychology: An International Review and British Journal of Management.

Scott A. Krebs is a doctoral candidate in the School of Psychology at The University of Queensland. His research focuses on knowledge sharing, leadership and virtual teams. 